\title{
Infection Control and the Need for Family-/Child-Centered Care
}

\author{
John Darby and Carla Falco
}

\section{Introduction}

Patient- and family-centered care (FCC) has been considered an important aspect of medical care over the last 20 years. FCC is focused on the mutually beneficial partnership and relationship between medical provider, patients, and families with an emphasis on collaboration [1]. This change in perspective to focus on patient- and family-centered care includes a shift away from the concept of families, especially parents and legal guardians, as visitors [2-6]. The key tenants of FCC include dignity and respect of the patient and family, information sharing, participation by the patient and family in the care and decision-making at the level they choose, and collaboration. FCC has been shown to improve patient outcomes [1, 7-13].

In the hospital setting, FCC espouses that family members are accepted as the ones who both know the patient best and are the primary support for the patient. Parents and legal guardians are treated as an extension of the patient; their importance is underscored frequently in the literature on visitation policies by the lack of limitations implemented for parents, legal guardians, or siblings [14]. Family presence at the bedside has been increasingly recognized as crucial for patient wellbeing [15]. More flexible visiting hours have been shown to improve patient outcomes in adult intensive care unit (ICU) patients [2, 16-21]. For example, visitation policies for family members have been a focus for change in ICUs with the advancement of FCC, including advocating for open visitation, i.e., visitation

\footnotetext{
J. Darby, MD ( $\triangle)$

Department of Pediatrics, Wake Forest School of Medicine,

Winston-Salem, NC, USA

e-mail: jdarby@wakehealth.edu

C. Falco

Department of Pediatrics, Section of Hospital Medicine, Baylor College of Medicine,

Houston, TX, USA
} 
without restrictions [22-26]. Private rooms within ICUs have also been cited to both support FCC and infection control [23].

Infection control within the hospital setting prioritizes patient safety from transmissible diseases. Infection control practices have the potential to greatly influence family centeredness because isolation practices can affect the ways that patient families are supported and affect how patients cope with hospitalization. Approaching infection control through the lens of FCC requires balancing patient safety and overall patient well-being through bonding with caregivers, family members, and visitors and engaging in activities to encourage normalcy during their hospitalization, including participating in play and pet therapy [27]. In this chapter, we explore this balance and will also address the psychosocial impact of isolation policies.

\section{Isolation Practices and Family Members}

FCC encourages the presence of family members, especially caregivers, to be at the bedside to participate in clinical decision-making because of their role as the primary support and strength for the patient [27]. FCC also regards caregivers as experts on their child with invaluable knowledge that is critical to excellent medical care; healthcare professionals are also called to support families in their caregiving and decision-making. The physical presence of family members is a consolation for patients and is essential for young children, but their presence can also pose a risk of transmissible disease at the same time. Isolation practices, including personal protective equipment (PPE) and limitation of visitation, are ways to mitigate that risk for patients, family members, and healthcare workers.

Evidence that visitors and family members pose a health risk to hospitalized patients is overall equivocal except in the case of childhood tuberculosis. Caregivers of pediatric patients with tuberculosis are the highest-risk population for transmitting infection within the hospital since they can be the child's primary source of disease [28-31]. Two studies in a pediatric hospital found that $15-17 \%$ of patients who were treated for tuberculosis had caregivers who received a new diagnosis of tuberculosis [29, 32]. Outbreaks have been traced back to adults caring or visiting children with tuberculosis (see section below). The infection control aproach recommended is to address the family as a unit and not simply isolate the patient individually [31]. Appropriate screening measures for tuberculosis include having parents wear a surgical mask until a chest x-ray can be performed; the use of N95 masks is not recommended since fit testing is not practical for visitors. These measures were shown to be cost-effective as screening tools [32].

More broadly, visitation policies, which do not include caregivers, have been examined to see how they affect hospital-acquired infections. One recent study by Washam et al. demonstrated that during the winter respiratory viral season, visitors were a source of infection; creating a standardized, visitation restriction policy decreased hospital-acquired viral pathogens on non-ICU floors and influenza infections overall [14]. Hospital-acquired infections were decreased by $37 \%$ through limiting visitation by nonsiblings and ill visitors. In the ICUs, only four nonparent, nonlegal 
guardian persons on a fixed list were permitted to visit; later in the study, they changed this policy to apply hospital-wide and to allow six persons on a fixed list to visit. Restricting visitors was also shown to decrease respiratory syncytial virus (RSV) infection in an open-room neonatal intensive care unit (NICU). Peluso et al. in 2015 published RSV surveillance data from 2001-2010 in their NICU [33]. In 2007, they restricted the visitation of children less than 13 years old during RSV season (OctoberMarch); they found less frequent RSV infections, both asymptomatic and symptomatic, with the more restrictive policy. The groups before and after 2007 were similar in characteristics, and the disease prevalence of RSV in the region remained constant during the study time period. Other studies in special units have examined the restriction of ill visitors and children as part of infection control bundles and seen a reduction in infections, for example, in adult bone marrow transplant (BMT) units and NICUs during RSV season [33, 34]. Some studies in adult ICUs have shown an increase in environmental contamination and even bioaerosols but no effect on the rate of hospital-acquired infections with liberalizing visitation policies; the same has been shown for NICUs [16, 35-39]. The bulk of research on infections via hand transmission has focused on healthcare workers [28, 40]. Yet, visitors have also been implicated in outbreaks of various pathogens (see section below).

Given the limited data available, guidelines for isolation practices and visitors have been published using expert consensus and take into account the specific pathogen, the disease manifestation of the infection, and the endemicity of the pathogen in both the hospital and community [14, 28, 41]. General recommendations for visitors have been published by the Society for Healthcare Epidemiology of America (SHEA) and recommend that all visitors should perform hand hygiene before entering and directly after leaving the patient's room, which has been shown to decrease pathogenic organisms $[42,43]$. Some institutions apply transmissionbased precautions only for healthcare workers where others include visitors in these policies. In a survey of SHEA members in 2014, 57\% of over 250 respondents indicated that they had the same requirements for isolation precautions (primarily in contact isolation) for visitors as for healthcare providers; however, this practice was not closely monitored for visitors. Until appropriate studies are performed, isolation precautions among visitors should be considered based upon pathogens, infectious condition, patient population, and local epidemiology in the hospital and community. Furthermore, hospitals should have specific policies regarding visitation that are feasible and can be enforced [28]. Other tenants of the SHEA Guidance are outlined in Table 4.1.

In the pediatric hospital setting, it is important to distinguish between visitors that have been exposed to the patient as household contacts and those who have less intense contact with the patient. Parents and caregivers are frequently exposed to the patient at home and often continue their vigil to care for their child in the hospital at the bedside overnight or for prolonged periods of time. Given the high likelihood of exposure that these parent caregivers have experienced and will continue to experience, it is not practical for caregivers to use PPE other than for standard precautions [14, 28]. In addition, concerns about bonding between caregivers and children have been cited as reasons to not fully enforce PPE use in parent caregivers; the psychosocial impact of isolation practices remains a topic for future research. 
Table 4.1 Transmission-based precautions for visitors $[14,28,41]$

\begin{tabular}{|c|c|}
\hline Isolation practice & Who should use \\
\hline $\begin{array}{l}\text { Contact precautions: } \\
\text { gowns and gloves }\end{array}$ & $\begin{array}{l}\text { Visitors to patients with enteric pathogens (e.g., } C \text {. difficile, norovirus) } \\
\text { Visitors to patient(s) with MRSA or VRE if they will be visiting } \\
\text { multiple patients (i.e., clergy) } \\
\text { Consider with: } \\
\text { Visitors to patients who are either colonized or infected with } \\
\text { extensively drug-resistant gram-negative organisms } \\
\text { Outbreaks } \\
\text { Visitors to a single patient with MRSA or VRE who are } \\
\text { immunocompromised or are unable to perform good hand hygiene }\end{array}$ \\
\hline $\begin{array}{l}\text { Droplet precautions: } \\
\text { surgical mask }\end{array}$ & $\begin{array}{l}\text { All visitors, except for those with extensive exposure to the patient } \\
\text { before admission (i.e., member of the patient's household) }\end{array}$ \\
\hline $\begin{array}{l}\text { Airborne precautions: } \\
\text { surgical mask }^{\mathrm{a}}\end{array}$ & $\begin{array}{l}\text { Visitors to patients who are on airborne precautions, except for those } \\
\text { with extensive exposure to the patient before admission }\end{array}$ \\
\hline Restricted visitation ${ }^{\mathrm{b}}$ & $\begin{array}{l}\text { Any visitor who is ill (e.g., active cough, fever, vomiting, and/or } \\
\text { diarrhea) } \\
\text { Outbreak or increased baseline rates } \\
\text { Consider with: } \\
\text { Nonsibling children during respiratory viral season } \\
\text { Consider limiting visitation to a fixed list of nonparent, nonlegal } \\
\text { guardian persons during winter respiratory viral season }\end{array}$ \\
\hline
\end{tabular}

${ }^{a}$ Caregivers of children with suspected tuberculosis should wear a surgical mask until a chest $\mathrm{x}$-ray is performed and reported as negative

${ }^{b}$ In cases of emerging pathogens that are highly contagious (e.g., Severe Acute Respiratory Virus Syndrome[SARS], Middle East Respiratory Syndrome Coronavirus [MERS-CoV], Ebola, etc.), guidance from updated health authorities (CDC and state health departments) is essential in developing specific visitation policies in those special circumstances. We would highly recommend consulting these authorities if a patient is suspected of having one of these pathogens.

Family members and other visitors are likely to have a variable compliance rate with infection control measures. Research shows that hand hygiene compliance is highly variable (from $<1 \%$ to $57 \%$ ) among visitors. At least two studies have shown that visitors only partially comply with contact precautions; most visitors who don gown and gloves neglect to perform hand hygiene [44, 45]. Efforts that improve hand hygiene practices of visitors include signs that accompany readily available alcohol hand rub and, in more extreme cases, a motion detection sensor [43, 46, 47]. Visitors' use of gown and gloves for contact precautions and the addition of masks for respiratory isolation are also highly variable: $40-60 \%$ and $23 \%$, respectively $[44,48]$. No studies have examined education of visitors regarding good hand hygiene or gown and glove use; in addition, no studies on isolation practices have distinguished between visitors and parents or caregivers at the bedside.

\section{Outbreaks}

There are select cases where visitors to patients have been cited as sources for the transmission of pathogens including tuberculosis, RSV, norovirus, and SARS [28, 49]. Outbreaks are defined by the Centers for Disease Control as the occurrence of 
more cases of a disease than expected in a given area or among a specific group of people over a particular period of time [50]. The screening and restriction of visitors, especially symptomatic visitors, is essential to prevent or control an outbreak. First, caregivers and adult visitors of pediatric patients with tuberculosis must be screened as described above. One report describes a tuberculosis outbreak that involved 24 children, including some immunocompromised patients, who had contact with a patient's mother with cavitary tuberculosis [51, 52]. An adult visitor was a source of two cases of latent tuberculosis infection in hospital staff members in another report [53]. Second, a report in 2005 of an RSV outbreak in a NICU suspected a sibling visitor to be the initial source which resulted in RSV infection in nine babies in open bassinets, five of whom required intubation and one required ECMO for 9 days [54]. The total hospital charge of the outbreak was $\$ 1.15 \mathrm{M}$. In response, control measures included limiting all visitors to those older than 13 years old who had no respiratory symptoms, contact precautions, and cohorting the infants infected with RSV. They also tested all NICU infants and administered palivizumab to uninfected infants, although the latter practice has since been discouraged by the AAP [55]. Third, norovirus, a highly contagious enteropathogen, frequently requires some type of visitor restriction $[56,57]$. At a minimum, symptomatic visitors should be restricted, which has shown to aid in outbreak control [56]. One report of a large outbreak involving more than 500 patients and staff resorted to restricting all visitors after the limitation of symptomatic visitors did not curb a norovirus outbreak [57]. The limitation of symptomatic visitors has been used to prevent the outbreak of respiratory viruses, including influenza [53, 58, 59]. Finally, during the 20032004 epidemic of severe acute respiratory syndrome (SARS), visitors to the hospital were a significant part of the transmission cycle, including transmission to hospital staff, other patients, and the community [60-63]. The control measures used first included using PPE for symptomatic visitors; later, visitor restriction and quarantine of both symptomatic individuals in their homes and of entire hospitals were used [63]. Screening measures of visitors and staff were also implemented, including body temperature screening and questionnaires.

Even in extreme circumstances such as outbreaks of highly contagious or novel infections, including but not limited to SARS, Middle East respiratory syndrome coronavirus (MERS-CoV), and novel-H1N1 influenza, when visitor restriction is in place, parents and caregivers of hospitalized children typically remain at the bedside. Their bonding with and support for the patient, combined with the likelihood that they were exposed previously to the infectious agent before admission, supports continued caregiver presence [28, 41]. Indeed, many of the recommendations by SHEA are intended to be adjusted for parents and caregivers. A case-by-case analysis should be made in situations where the patient contracts an infection after admission; usually caregivers still remain at the bedside unless they themselves are immunocompromised. Visitation by other family members besides parents or caregivers depends on the infectious organism, the timing of illness, and the degree of contact that the family member had with the patient before and after admission. Those with less frequent contact with the patient should follow the isolation guidance outlined in Table 4.1. 


\section{Sibling Visitation}

In pediatrics, while parents have transitioned from being visitors to being an extension of the patient themselves and are indispensable to care and medical decisionmaking, siblings are still considered visitors. Yet, hospitals can offer a more family-centered environment by supporting the attachment between pediatric patients and their siblings [64]. The American Academy of Pediatrics shifted the perspective on sibling visitation in the 1980 s by encouraging restrictions to be liberalized to allow children and siblings less than 12 years old to visit hospitalized children. They stated that concerns over infection control were not evidence-based $[64,65]$. Hospitals then started to encourage sibling presence in the hospital [66]. Since then, a small body of literature has shown that in certain areas of the hospital or during certain times of year, for example, RSV and influenza season, restrictions on child and sibling visitation remain an important tool in infection control and prevention [14, 34, 67]. Each hospital should consider the necessary balance between family-centered care and sibling visitation with the importance of infection control measures to prevent transmission of pathogenic organisms and outbreaks.

With a focus on family-centered care, sibling visitation facilitates the entire family's adaptation to a child's hospitalization [68]. The limited research available on the effect of sibling separation in the setting of hospitalization suggests that it is stressful to both the patient and well sibling and disrupts the family structure [69-72]. Well siblings experience a change in family routine and in family focus and separation from their parents [73-75]. As a result, they can experience loneliness, worry, and decreased sleep [75-79]. Siblings of hospitalized children tend to have more emotional and behavioral problems, which are similar to the effects on siblings of children with a chronic illness or disability [75]. The anxiety that parents and siblings feel can then be transferred to the hospitalized child [80]. Sibling visitation in the hospital mitigates the disruption the family experiences and supports the family unit and family continuity [68]. Sibling visitation is also a way to diminish the negative emotional and behavioral effects on well siblings [68, 81, 82]. Child life programs within the hospital often provide education to siblings while also caring for the hospitalized child [80, 83, 84]. Sibling visitation also encourages the hospital staff to view the family as a unit, which enhances family-centered care [68, 85].

Since the AAP's statement encouraging sibling visitation, there has been more literature published about the most significant balancing measure for sibling visitation: infection control, especially with newborns and NICU patients. It is known that younger children have a "relatively high frequency of asymptomatic viral shedding and difficulties adhering to basic respiratory etiquette and hand hygiene practices" [67, 86]. Initially, studies examined the bacterial colonization of healthy newborns who were visited by a sibling as a marker for risk of infection and found no cause for concern. In 1980, Umphenour examined nasal and umbilical swabs of newborns at admission and discharge in both a control group $(N=214)$ and intervention group $(N=182)$ with sibling visitation [87]. Of note, siblings who were obviously ill were asked to not come to the hospital; children that did visit underwent hand hygiene with an iodine scrub before interacting with the newborns who 
were rooming-in with their mothers. There was no difference in the two groups in terms of bacterial colonization in the newborn. Similar studies yielded the same results in support of well siblings visiting well newborns assuming aggressive hand hygiene is adhered to $[82,88,89]$. A survey of 69 hospitals showed that the majority of hospitals have an open visitation policy for siblings of newborns; however, rarely do hospitals observe visiting siblings for signs of illness [90]. Furthermore, more recent studies have shown that siblings can be a source of infection in the NICU. A report in 2005 of an RSV outbreak in a NICU suspected a visiting sibling as being the source of RSV that infected nine babies with serious consequences (as discussed above) [54]. In 2015, Peluso published data from their own NICU surveillance practices from 2001-2010 [33]. During the 2001-2002 season, they noted an increase in RSV infections after they heeded the AAP's encouragement to liberalize sibling visitation [65]. After they implemented age-based restrictions during RSV season (October-March), they found less frequent RSV infections, both asymptomatic and symptomatic. They suggest that applying visitation restriction can prevent RSV infection in open-room design NICUs but that it should be applied carefully so as to support families as much as possible. Studies examining the infection risk to hospitalized patients with sibling visitation outside the NICU are lacking. However, restriction of children, both siblings and nonsiblings, visiting the hospital remains a resource for infection control in times of outbreak [91].

Currently, there are no universal standards for sibling visitation in the NICU or hospital-wide [14, 82]. The American Academy of Pediatrics' Committee on Infectious Diseases (AAP Red Book) recommends that siblings be screened for infection by a healthcare professional and that the appropriate documentation should be made [67]. If a sibling was known to be exposed to communicable disease, then their visit should be postponed. They also recommend that all vaccines be up to date, including influenza vaccine, and that these visiting well children should only visit their sibling and not be in contact with other patients. Each institution must evaluate the feasibility and process for these recommendations as they develop policies and procedures for their hospitals. The most important recommendation for all visitors, but especially siblings, is proper hand hygiene prior to and after visiting. One recent study at a quaternary children's hospital on healthcare-acquired respiratory infections found a $37 \%$ reduction in infections with a standardized visitation policy [14]. The policy did not limit sibling visitation but did exclude nonsibling children during the winter respiratory viral season. An informal review of the visiting policies listed on the websites of children's hospitals across the USA shows that parents have no restrictions on visitation. Siblings under 12-14 years old must be well to visit. Some hospitals limit sibling visitation depending on different factors, including specific visiting hours, contact isolation, influenza season, and location in the hospital $[92,93]$. Special units like NICUs, BMT units, and PICUs have more restrictive policies; there, well siblings under the ages of 3-5 years old are usually prohibited from visiting [14]. Some special units require evidence of adequate of vaccination [94]. Research on ICU visitation has found that there is benefit to family and sibling visitation [85]. We recommend facilities review or draft sibling visitation policies with the perspective of the benefits of FCC while incorporating 
Table 4.2 Sibling visitation policy recommendations

\begin{tabular}{l|l|l}
\hline Hospital unit & $\begin{array}{l}\text { Sibling visitation } \\
\text { recommendation }^{\mathrm{a}}\end{array}$ & $\begin{array}{l}\text { Recommendation during influenza } \\
\text { season or outbreak }^{\mathrm{a}}\end{array}$ \\
\hline $\begin{array}{l}\text { Acute care floor, including } \\
\text { patients with contact } \\
\text { precautions }\end{array}$ & Open sibling visitation & Open sibling visitation \\
\hline NICU & $\begin{array}{l}\text { Siblings older than } \\
\text { 3 years old }\end{array}$ & Siblings older than 13 years old \\
\hline PICU & $\begin{array}{l}\text { Siblings older than } \\
\text { 3 years old }\end{array}$ & Siblings older than 13 years old \\
\hline $\begin{array}{l}\text { BMT or } \\
\text { immunocompromised } \\
\text { patients }\end{array}$ & $\begin{array}{l}\text { Siblings older than } \\
\text { 3 years old }\end{array}$ & Siblings older than 13 years old \\
\hline
\end{tabular}

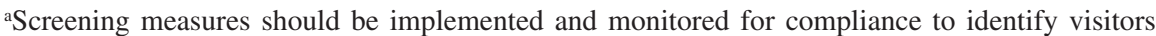
with cough, rhinorrhea, fever, rash, vomiting, and diarrhea. Siblings who are ill should not visit the hospital

infection control considerations. Suggestion of a framework for these discussions with key stakeholders, including patient advocacy councils, is outlined in Table 4.2. Policies need to include who conducts the screening and training for those staff. Any ill siblings should not visit the hospital, and well siblings who do visit should perform standard hand hygiene.

Sibling visitation is a means to promote family-centered care by honoring the family unit; this worthwhile focus of medical care must remain in balance with concerns for infection control. The safety of the hospitalized child remains the ultimate goal such that, whether siblings have visited or not, a healthy reunion of the family can occur at discharge.

\section{Pet Therapy}

\section{Overview}

Animals in pediatric healthcare facilities have become commonplace and pose important infection control considerations. The following subchapter will outline some of the proposed benefits of animals on pediatric health, potential infection risks, and outline recommendations for infection control.

Children come into contact with animals outside of healthcare facilities on a regular basis. A national poll conducted in 2017 found that $68 \%$ of households contain a pet with $48 \%$ of households containing a dog and $38 \%$ containing a cat [95]. Inside healthcare facilities, there has been increased presence of animals with the growth of animal-assisted activities (AAA) and service animals. Additionally, some facilities may allow visitation from personal pets to hospitalized patients, especially in chronic care or end-of-life situations. AAA, animal-assisted therapy (AAT), pet therapy, and pet volunteer programs are all terms that have been used to describe various healthcare animal programs. AAT specifically refers to sessions conducted 
by trained therapists, typically the handler and animal, and are structured, organized visits with individualized patient goals. For the purpose of this discussion, the term animal-assisted interventions (AAI) will be used to encompass activities and therapies conducted with animals in the healthcare setting. Animals in healthcare (AHC) is a broad term that encompasses personal pet visitation as well.

\section{Benefits of Animals in Healthcare}

The benefits of animals in healthcare facilities are many. Studies conducted in adult psychiatric patients have shown that the use of AAI leads to an increase in selfesteem, self-determination, and a decrease in positive psychiatric symptoms and emotional symptoms [96]. The use of AAI in elderly patients in healthcare facilities has also shown positive impacts including a decrease in depressive symptoms, significant decreases in systolic blood pressure, and decreases in anxiety [97, 98]. Specifically in pediatric patients, a range of positive benefits have been observed including decreased anxiety, lower pain scores, and positive parental perceptions of child confidence, mood, and happiness [99-101]. Despite a lack of high-quality randomized controlled trials, the pediatric medical community has been accepting of AAI. Hospital staff members, as well as parents of patients, are generally very receptive to animals in healthcare facilities. This trend is consistent with the overall FCC movement and attempts to address the stresses of hospitalization for children and families. The use of AAI can make the hospital environment seem more familiar, provide distraction, enhance quality of life, and, in some cases, achieve specific therapy goals including promoting improvements in physical, social, emotional, or cognitive function. Consistent with the concepts of FCC, AAI takes a humanistic approach to patient care. With the growing presence of AHC however, there comes some degree of risk.

\section{Risks of Animals in Healthcare}

Studies and discussions surrounding the risk of animals in healthcare facilities have focused on the risk of infection, allergies, and bodily injury from bites and scratches. With specific regard to infection risk, many published studies have focused on the potential for animal to human transmission of diseases. Swabs taken from dogs used in pet visitation programs have isolated many transmissible bacteria including toxigenic Clostridium difficile, Salmonella, Toxocara canis, Ancylostoma caninum, Giardia, Escherichia coli, Malassezia pachydermatis, Pasteurella spp., and Trichophyton mentagrophytes [102]. Other reports have found the presence of healthcare-associated strains of methicillin-resistant Staphylococcus aureus (MRSA) in several species including dogs and cats. Additionally, there have been reports of hospital outbreaks of zoonoses although most occur when hospital personnel, such as nurses or operating room staff, are colonized or infected by pets or working animals kept in the home environment [103-107]. One notable exception 
is a described MRSA outbreak, which occurred in a geriatric rehabilitation ward and was traced to a cat that roamed freely inside the hospital [108].

Despite the cited infection concerns, the overall risk of zoonosis transmission from animals to humans in healthcare facilities is likely very low, albeit the literature is rather sparse in this area. In part the low risk of transmission from animals to humans in the healthcare setting may be a reflection of dogs being used primarily in AAI as opposed to other animals with a higher risk of transmission of zoonotic infections (such as reptiles). Given the high prevalence of animals in American households, many patients will return to animal contact after leaving the hospital. Additionally, rates of zoonotic infections in the general American public are also relatively low. One study noted no increase in hospital infections after the introduction of AAI [100]. Additionally, a review of the literature published in 2016 noted that with appropriate screening precautions, risks could be effectively mitigated [109]. Many of these risks may be effectively prevented with appropriate selection of patients and animals along with adherence to published guidelines and implementation of local facility protocols. With these preventative measures, the benefits of animals in healthcare facilities likely greatly outweigh risks.

\section{Guidelines to Minimize Infection Risk in Animals in Healthcare}

Several published guidelines exist to guide facilities in establishing precautions and security measures for minimizing risk from AAI and animals in healthcare facilities. Notably, in 2008, the American Journal of Infection Control published a set of guidelines established through a working group of expert stakeholders and including evidence-based statements [102]. Additionally, in 2015, the SHEA published recommendations to minimize risks of animals in healthcare [110]. The Centers for Disease Control (CDC) has published recommendations and so has the AAP Red Book [111, 112]. Some of the basic principles of animals in healthcare facilities and AAI are discussed in Table 4.3.

Table 4.3 Recommendations related to animal-assisted interventions

\begin{tabular}{l|l}
\hline Stakeholders & Recommendation \\
\hline $\begin{array}{l}\text { Prior to hospital visit } \\
\text { hospital or }\end{array}$ & $\begin{array}{l}\text { Individual facilities should develop guidelines and policies to minimize } \\
\text { the risks of injury or transmission of pathogens from animals to } \\
\text { humans in the healthcare setting. Policies should be developed in } \\
\text { consultation with physicians, nursing staff, infection control specialists, } \\
\text { risk management, and veterinarians }\end{array}$ \\
\hline Medical providers & $\begin{array}{l}\text { Animal visits to patients should be approved by the primary medical } \\
\text { provider after consideration of the risks and benefits. A history of } \\
\text { allergic reactions with animal contact, a fear of animals, and the } \\
\text { patient's medical condition should be part of this consideration } \\
\text { Verbal or written consent should be obtained from patients or } \\
\text { caretakers prior to visitation from facility animals and their handlers }\end{array}$ \\
\hline
\end{tabular}


Table 4.3 (continued)

\begin{tabular}{l|l}
\hline Stakeholders & Recommendation \\
\hline Animal handlers and & $\begin{array}{l}\text { Visiting animals should have veterinary documentation of good health } \\
\text { including a certificate of immunization from a licensed veterinarian and } \\
\text { an annual fecal exam for enteric parasites. The animal should be } \\
\text { checked for any skin infections, including those caused by bacteria, } \\
\text { ectoparasites such as fleas and ticks, or superficial dermatophytes } \\
\text { Animals used in AAT and volunteer pet programs should have } \\
\text { documentation of temperament testing or prior behavior assessment by } \\
\text { a trained volunteer or employee } \\
\text { Animals should be well groomed and recently bathed prior to facility } \\
\text { visitation }\end{array}$ \\
\hline
\end{tabular}

Precautions and visitation exclusions

\begin{tabular}{l|l}
\hline $\begin{array}{l}\text { Hospital or } \\
\text { healthcare facilities, } \\
\text { medical providers, } \\
\text { animal handlers }\end{array}$ & $\begin{array}{l}\text { Patients should be excluded if there are isolation restrictions, undressed } \\
\text { wounds, and/or burns, if there is a sterile field present, or if there is a } \\
\text { severe immunodeficiency } \\
\text { Animal interaction in high-risk patient areas such as the intensive care } \\
\text { units (including cardiac intensive care), hematology-oncology unit, and } \\
\text { transplant units should be considered cautiously and approved by } \\
\text { medical leadership }\end{array}$ \\
\hline Medical providers & $\begin{array}{l}\text { Patients with medical devices including indwelling catheters, feeding } \\
\text { tubes, tracheostomy tubes, or oxygen delivery devices should undergo } \\
\text { preparation to secure and cover devices prior to animal visits in order } \\
\text { to prevent body or mouth contact and/or dislodgement of the device }\end{array}$ \\
\hline $\begin{array}{l}\text { Hospital or } \\
\text { healthcare facilities, } \\
\text { animal handlers }\end{array}$ & $\begin{array}{l}\text { Animals excluded from visitation should include reptiles and } \\
\text { amphibians, nonhuman primates, hamsters, gerbils, mice, rats or other } \\
\text { rodents, and other animals that have not been litter trained, such as } \\
\text { birds. Fish may be considered on a case-by-case basis }\end{array}$ \\
\hline
\end{tabular}

During animal visit

Animal handlers $\quad$ Animals should be transported around the facility by a trained handler or employee familiar with the animal. Pet carriers or a short leash (4 feet or less) should be used. In the cases of personal pet visitation, it may be appropriate that a family member carries or walks the animal with direct facility employee supervision

Contact with animal dander, saliva, urine, or feces should be minimized

Medical providers Facility personnel should supervise all animal visits. Child life staff may be trained in patient-animal interactions and may provide guidance and oversight. Supervisors should be trained in facility policies including how to respond to cases of animal bites or animal defecation or vomiting

Medical providers and animal handlers
Before and after animal contact, patients, staff, and visitors should perform hand hygiene with facility-approved alcohol-based foams or gels or wash their hands with soap and water if their hands are visibility soiled. Areas of the facility with animal contact should be cleaned and disinfected after the animal visit is complete

Take prompt action if an animal bite or scratch occurs. The animal should be removed from the facility, and the event should be reported to appropriate authorities including infection control staff and animal program coordinators. The bite or scratch should be quickly treated according to medical best practices 


\section{Play Areas}

Family-centered care at its core is patient-centered care. In pediatric hospitals, normalization of an unfamiliar environment is a critical part of supporting hospitalized children [80]. The importance of play and child life programs that facilitate and participate in patient play has grown with the shift toward family- and patientcentered care [80]. Play has shown to promote child development and create a sense of normalcy [80, 113]. Play can also be a means for expression and learning about the hospital environment. Playrooms are "an essential part of creating a normal childhood environment for ill children" since they bring an outside, familiar habitat into the hospital [113]. Some hospitals welcome siblings in the playroom to further enhance the family-centered care although this is not universally accepted. Playrooms universally include toys, which have been shown to decrease the anxiety hospitalized children experience [114].

Playrooms can also be a source of infection as research has shown that children that congregate often spread communicable diseases [115-118]. Specifically, studies of daycare and hospital toys have shown that they can be a source of pathogens $[119,120]$. Contamination with pathogenic organisms can happen within a week of a toy being introduced into the hospital environment, as demonstrated by a study of sterilized teddy bears that were given to hospitalized children [121]. The teddy bears were originally part of a campaign to promote hand hygiene within the hospital. Hospital toys have also been the source of rare outbreaks. For example, an outbreak of Pseudomonas occurred in a pediatric oncology unit related to bath toys and their container [122]. On another oncology ward, an outbreak of rotavirus was related to lack of regular cleaning of playroom toys [123]. The material of the toys affects the likelihood that they will contain bacteria, with plastic being the most prevalent followed by metal and other materials [124]. In a study in an Argentinian children's hospital, the toys that were handled by patients in a playroom were contaminated $87 \%$ of the time by bacteria from the Staphylococcus genus [125]. Playroom toys have been noted to be colonized with coagulase-negative staphylococci in $38.8-45.5 \%$ of cases $[124,125]$. S. aureus are also found on toys with one study showing $28.8 \%$ of toys contaminated by this organism. Of all the $S$. aureus strains found in that study of playroom toys, $21.4 \%$ were resistant to oxacillin. In a study in a Peruvian pediatric hospital, of 40 toys that were tested, $20 \%$ had $S$. aureus recovered in culture [126]. These percentages of $S$. aureus are not unexpected, however, since between 20 and $40 \%$ of the general population are colonized and this organism is known to be prevalent in the environment [125]. While these studies examine the level of contamination with $S$. aureus, they make no mention of the prevalence of $S$. aureus infections or any relationship of infections to contact with the contaminated toys. For both bacteria and viruses, the presence of contamination does not always correlate with the risk of infection since the exact infectious doses of each organism are difficult to determine [86].

Playroom surfaces can also harbor pathogens, including bacteria and viruses. A number of clinically important viruses can survive for prolonged periods of time, especially on doors, high hand-touch sites, and work surfaces [86]. Viruses like 
norovirus, rotavirus, and astrovirus have been found in pediatric hospital wards [42, 86]. Surface contamination with rotavirus, adenovirus, and norovirus are frequently associated with healthcare settings [127]. In one study, viral contamination within a hospital unit was associated with areas trafficked by parents of hospitalized children [42]. This suggests that playrooms, where parents and hospitalized children frequent, are more likely to have viral contamination. Again, the exact level at which contamination leads to infection, however, is difficult to determine.

Mitigating the risk of infection from the playroom is crucial to the safety of hospitalized children. Our recommendations are that all children's hospitals should have a playroom that is readily accessible to patients. In addition, no one who is on airborne, droplet, or contact precautions should visit the playroom. The AAP Committee on Infectious Diseases recommends that siblings should not visit the playroom, albeit there is no robust evidence to support this recommendation [67]. If family members are allowed in the playroom, screening of siblings or adult caretakers for acute illness (fever, cough, vomiting, diarrhea, or rash) is advised prior to entering the playroom. Notably, one study focusing on family-centered care argues for including siblings in the playroom as long as they are screened appropriately $[67,113]$. Regular cleaning of toys and hard surfaces inside the playroom are important to break the chain of transmission of pathogenic organisms [128]. We recommend the selection of toys and containers for toys made from material that are amenable to washing with soap and water as well as $70 \%$ alcohol, like plastic, acrylic, rubber, and metal [125]. Regular cleaning of the toys is recommended, whether it be after each use or calendar-based (e.g., daily). Cleaning and/or disinfecting surfaces within the playroom should also be on a schedule and tailored to the individual playroom with a focus on high-touch surfaces [119, 128]. One study demonstrated a decrease in surface viral contamination with daily floor cleaning with surface cleaning twice daily while glass screens and windows were cleaned weekly [42].

\section{Adverse Impacts of Contact Precautions on Patient Care}

Since the onset of infection control practices, concerns have been raised about the potential impact to patient care. Historically, much of the concern centered on the social stigma that comes along with isolation. In the current hospital environment however, and specifically within pediatrics, isolation precautions are commonplace and may occur in a large percentage of patients. As previously noted, infection control decisions require a balance between patient safety and the need for FCC and patient well-being. Research to date examining the potential negative impacts of isolation practices has largely been conducted in adult patients and has sought to investigate if isolated patients, when compared to non-isolated patients, experience the following negative effects: a decrease in the quality of care, fewer interactions with healthcare workers, delays in care and adverse events, the presence of symptoms of depression and anxiety, and lower satisfaction with their care. Providers and families of hospitalized children have also worried about the psychosocial impacts 
of isolation practices. The following subchapter outlines some of the conflicting reports regarding the potential for untoward effects.

\section{The Impact of Contract Precautions on the Quality of Care}

For decades, a principal concern has been that patients isolated for infection control, in addition to social stigmatization, may receive lower quality care. Several studies conducted in adult populations have documented that providers spent less time in patient rooms when patients were on isolation precautions regardless of the setting (wards or intensive care unit) and were less likely to enter the rooms of isolated patients when compared to non-isolated patients [129-131]. Another report published in 2003 noted that adult patients isolated for MRSA colonization or infection were less likely to have vital signs documented, had fewer daily physician progress notes, had twice as many preventable adverse events, and were more likely to formally complain about their care to the hospital when compared to control (nonisolated) patients [132].

These reports are balanced, however, by two other studies conducted in pediatric settings which showed no differences in the quality of care or direct patient contact between isolated and non-isolated patients. The first, published in 1989, was conducted prospectively in a pediatric intensive care setting and demonstrated no difference in the frequency of contact by hospital personnel or family members between patients receiving isolation precautions and those receiving standard precautions [133]. Additionally, it was reported that patients tolerated contact isolation well, and there was no increase in adverse events between groups. The second study published in 2008 was a blinded prospective observational study and additionally reported no differences in time spent with isolated vs non-isolated patients on an acute care, general pediatrics service [134]. Study investigators reported on other quantitative measures including the number of organ systems examined, vital signs recorded, and other balance measures. Parent satisfaction questionnaires showed no differences in the caregiver perceived quality of care between isolated and nonisolated patients. These two studies cast doubt on the theory that the quality of care and patient satisfaction may be negatively impacted by the use of contact precautions, especially in pediatric care. Larger, multicenter studies focusing on pediatric inpatient care are needed however to better understand the true impacts of contact precautions on children's care and caregiver satisfaction.

\section{The Psychosocial and Behavioral Impacts of Contact Precautions}

Isolation practices can have profound psychosocial and behavioral impacts, however, and providers should strive to understand the implications of placing a patient on contact isolation. A hospital can be a frightening and anxiety-producing place for pediatric patients. To add to this, when a physician or hospital staff member enters a patient room dressed in a mask, gown, gloves, and/or other personal protective equipment (PPE), this will likely only worsen a sense of fear in a child. Contact 
precautions often may preclude the patient from leaving the room or moving to other areas of the hospital. A child's reaction to infection control practices is influenced by their age, development, and potentially parental or caretaker reaction to the measures.

In adult studies, the data is again mixed. Higher depressions scores, anxiety scores, and anger-hostility scores have all been reported in isolated patients when compared to non-isolated patients suggesting that infection prevention measures have negative impacts on patient psychological well-being. [135] Patients have reported increased fear and loneliness while in isolation for infection reasons as well. It is worth noting that many of these symptoms seem to increase as the length of time in the hospital increased and short-term isolation practices may be less associated with increased depression and anxiety [136]. Other studies, however, have shown no differences in development of increased depression, anxiety, or other negative emotions such as sadness, anger, and worry [137, 138].

In children, the psychological and behavioral effects of isolation practices are perhaps harder to quantify, and there is lack of recent literature in this area. A review published in 2013 draws attention to the lack of current literature examining the pediatric patient experience while in hospital isolation [139]. This review notes that much of the research conducted on the developmental impacts of source isolation is dated, occurring in the 1970s and 1980s, and often involves single patients, with a single disease process such as severe combined immunodeficiency, who were isolated for prolonged periods (months to years). More recent literature has examined patient and caretaker perspectives during outbreaks such as the 2003 SARS outbreak [140, 141]. These studies provide examples of extreme infection prevention precautions including complete separation of the child from the caregiver. Not unexpectedly, this form of isolation was associated with significant emotional distress including reported feelings of sadness, loneliness, worry, and fear among both patients and their caretakers. More common reasons for patient isolation, including upper and lower respiratory track viral infections, gastroenteritis, draining lesions and wounds, and MRSA infections to name a few, may affect a wide range of patients of different ages and cultures and may result in a range of time in the hospital. The psychosocial impact of contact precautions on this patient group deserves further investigation.

More has been written about the fear children experience when hospitalized or facing medical care. Forsner et al. comment that medical care may cause profound fear and is even perceived as threatening to the very existence of the child [142]. School-age children often use magical and fantastical thinking to interpret the world around them, and medical care may be perceived as a danger or a "monster" that threatens to destroy the child, according to Forsner and colleagues. It is easy to see that the use of PPE may only worsen this perception by pediatric patients. Forsner reports as well that children under 7 years of age rely heavily on appearances when making assessments of potential threats. PPE can distort normal human appearance and prevent the ability of a child to interpret who is friendly and who is threatening. Children have expressed a sense of feeling overpowered and helpless in the medical environment. Hospital staff entering a room may outnumber the child and his or her parents or caretakers and this contributes to a sense of powerlessness. Medical environments include equipment necessary for providing care that may be perceived by 
a young child as being designed to cause harm including needles, other sharp objects, and even blood pressure cuffs. The addition of PPE can only add to this feeling that the intent of medical personnel is to harm the child. Children's narratives, as studied by Forsner, suggest that fear experienced is magnified when children feel objectified and their own feelings are not validated by those performing a procedure or examination. PPE may obscure the child's ability to see a provider smile, express empathy, or convey comforting gestures [142].

Confinement to a space due to isolation precautions is potentially detrimental situation for a child as well. Isolation may prevent normalization activities such as trips to a playroom, library, or social events with other children. Especially in younger children, confinement to an area may be perceived as punishment. In the home environment, children may be punished by being told to stand in a corner or being sent to their room. Inability to leave a hospital room likely triggers strong associations to punishment for young children. [142] Even in older children, the inability to socialize and leave a confined space may negatively affect self-esteem.

\section{Mitigation of the Negative Effects of Contact Precautions}

Medical providers should make every effort to minimize the potential for negative effects of isolation precautions. The first step toward reducing untoward effects is simply to avoid overuse. Providers should be cognizant of the potential for negative impacts and work closely with hospital infection control departments to effectively identify patients who are appropriate for contact precautions and appropriate timing for discontinuation of these precautions. National guidelines and recommendations (as outlined in this text) serve to guide practitioners toward the judicious use of these precautions. For patients on contact precautions, there should also be a daily reassessment by the medical team to determine if precautions can be removed. In the busy clinical environment, it is easy to overlook details such as contact precautions, and diligence in this area is necessary for all providers involved in the care of the child. The presence or absence of isolation precautions may be a memorable experience for families and patients and influence their perceived care. In the many instances, when contact precautions cannot be avoided, however, physicians and staff should consider bundling care and minimizing interruptions to the patient's day as well as minimizing the number of care providers in the room at a given time.

Adequate communication regarding the reasons for contact precautions is another important step to minimizing the negative effects. In a study published in 2000 in Nursing Standard, study authors note that clear and frequent communication about the need for contact precautions was highly impactful on patient satisfaction [143]. Similarly, in children, age appropriate communication and explanations regarding the reasons for contact isolation is very important. When speaking to a young school-aged child, for example, using the words, "since you have the flu, when you cough, you could spread germs to other children and adults and make them sick too, and for this reason, we need you to stay in this room right now," is preferable to "you have to stay in your room because you are sick." In the first example, specific language is used to clearly state why precautions are necessary. 
Many pediatric facilities have access to child life trained staff who can be an invaluable resource to aiding the child and family with normalization activities, developing a routine, and integrating the "outside" into the patient's room. Decorating the room, bringing developmental activities to the patient room, and familiarizing the child with the hospital environment and equipment are all key strategies that can help with coping and anxiety relief especially in the setting of isolation practices. Familiarity with PPE may help decrease anxiety and fear, and when possible, care providers can allow children to touch and, when appropriate, play with equipment such as gloves and gowns. The use of technology can be highly effective in confronting the challenges of isolation practices as well. Teenagers and young children are increasingly engaged in social media, texting, and using video conferences with friends and family members, and the use of these technologies can help with social stimulation and relieve boredom. Cystic fibrosis patients, for example, are a particular group of patients who are often isolated in the hospital environment and have limited contact with peers who also have cystic fibrosis so as to decrease the bacterial and fungal pulmonary colonization risk. Texting, online chat rooms, and social media can all be very beneficial in connecting these teenage patients at an age when social connectedness and normalization can be very important to self-image.

\section{References}

1. Patient- and family-centered care. http://www.ipfcc.org/about/pfcc.html. Accessed 15 Jan 2018.

2. Adams S, Herrera A, Miller L, Soto R. Visitation in the intensive care unit: impact on infection prevention and control. Crit Care Nurs Q. 2011;34(1):3-10.

3. Dingeman RS, Mitchell EA, Meyer EC, Curley MA. Parent presence during complex invasive procedures and cardiopulmonary resuscitation: a systematic review of the literature. Pediatrics. 2007;120(4):842-54.

4. Dokken D, Parent K, Ahmann E. Family presence and participation: pediatrics leading the way ... and still evolving. Pediatr Nurs. 2015;41(4):204-6.

5. Institute for Patient- and Family-Centered Care. Changing hospital "visiting" policies and practices: supporting family presence and participation. 2010. http://www.ipfcc.org/ resources/visiting.pdf. Accessed 16 Jan 2010.

6. Muething SE, Kotagal UR, Schoettker PJ, Gonzalez del Rey J, TG DW. Family-centered bedside rounds: a new approach to patient care and teaching. Pediatrics. 2007;119(4):829-32.

7. Bertakis KD, Azari R. Patient-centered care is associated with decreased health care utilization. J Am Board Fam Med. 2011;24(3):229-39.

8. Bertakis KD, Azari R. Determinants and outcomes of patient-centered care. Patient Educ Couns. 2011;85(1):46-52.

9. Goldfarb MJ, Bibas L, Bartlett V, Jones H, Khan N. Outcomes of patient- and familycentered care interventions in the ICU: a systematic review and meta-analysis. Crit Care Med. 2017;45(10):1751-61.

10. Stewart M, Brown JB, Donner A, et al. The impact of patient-centered care on outcomes. J Fam Pract. 2000;49(9):796-804.

11. Sweeney L, Halpert A, Waranoff J. Patient-centered management of complex patients can reduce costs without shortening life. Am J Manag Care. 2007;13(2):84-92.

12. Wolff JL, Roter DL. Family presence in routine medical visits: a meta-analytical review. Soc Sci Med. 2011;72(6):823-31. 
13. Anonymous. Data trends. Measuring the cost benefits of family-centered care. Healthc Financ Manage. 2003;57(9):118.

14. Washam M, Woltmann J, Ankrum A, Connelly B. Association of visitation policy and health care-acquired respiratory viral infections in hospitalized children. Am J Infect Control. 2017;46(3):353-5.

15. Slota M, Shearn D, Potersnak K, Haas L. Perspectives on family-centered, flexible visitation in the intensive care unit setting. Crit Care Med. 2003;31(5 Suppl):S362-6.

16. Fumagalli S, Boncinelli L, Lo Nostro A, et al. Reduced cardiocirculatory complications with unrestrictive visiting policy in an intensive care unit: results from a pilot, randomized trial. Circulation. 2006;113(7):946-52.

17. Usher BM, Hill KM. Family visitation in the adult intensive care unit. Crit Care Nurse. 2016;36(1):e15-8.

18. Berwick DM, Kotagal M. Restricted visiting hours in ICUs: time to change. JAMA. 2004;292(6):736-7.

19. Simpson T, Shaver J. Cardiovascular responses to family visits in coronary care unit patients. Heart Lung. 1990;19(4):344-51.

20. Kleman M, Bickert A, Karpinski A, et al. Physiologic responses of coronary care patients to visiting. J Cardiovasc Nurs. 1993;7(3):52-62.

21. Ramsey P, Cathelyn J, Gugliotta B, Glenn LL. Visitor and nurse satisfaction with a visitation policy change in critical care units. Dimens Crit Care Nurs. 1999;18(5):42-8.

22. Davidson JE, Powers K, Hedayat KM, et al. Clinical practice guidelines for support of the family in the patient-centered intensive care unit: American College of Critical Care Medicine Task Force 2004-2005. Crit Care Med. 2007;35(2):605-22.

23. Davidson JE, Aslakson RA, Long AC, et al. Guidelines for family-centered care in the neonatal, pediatric, and adult ICU. Crit Care Med. 2017;45(1):103-28.

24. Sims JM, Miracle VA. A look at critical care visitation: the case for flexible visitation. Dimens Crit Care Nurs. 2006;25(4):175-80.

25. Hupcey JE. Looking out for the patient and ourselves - the process of family integration into the ICU. J Clin Nurs. 1999;8(3):253-62.

26. Chapman DK, Collingridge DS, Mitchell LA, et al. Satisfaction with elimination of all visitation restrictions in a mixed-profile intensive care unit. Am J Crit Care. 2016;25(1):46-50.

27. Committee on Hospital Care, Institute for Patient- and Family-Centered Care. Patient- and family-centered care and the pediatrician's role. Pediatrics. 2012;129(2):394-404.

28. Munoz-Price LS, Banach DB, Bearman G, et al. Isolation precautions for visitors. Infect Control Hosp Epidemiol. 2015;36(7):747-58.

29. Munoz FM, Ong LT, Seavy D, Medina D, Correa A, Starke JR. Tuberculosis among adult visitors of children with suspected tuberculosis and employees at a children's hospital. Infect Control Hosp Epidemiol. 2002;23(10):568-72.

30. Jensen PA, Lambert LA, Iademarco MF, Ridzon R, Centers for Disease Control and Prevention. Guidelines for preventing the transmission of Mycobacterium tuberculosis in health-care settings, 2005. MMWR Recomm Rep. 2005;54(RR-17):1-141.

31. Cruz AT, Starke JR. A current review of infection control for childhood tuberculosis. Tuberculosis. 2011;91(Suppl 1):S11-5.

32. Cruz AT, Medina D, Whaley EM, Ware KM, Koy TH, Starke JR. Tuberculosis among families of children with suspected tuberculosis and employees at a children's hospital. Infect Control Hosp Epidemiol. 2011;32(2):188-90.

33. Peluso AM, Harnish BA, Miller NS, Cooper ER, Fujii AM. Effect of young sibling visitation on respiratory syncytial virus activity in a NICU. J Perinatol. 2015;35(8):627-30.

34. Garcia R, Raad I, Abi-Said D, et al. Nosocomial respiratory syncytial virus infections: prevention and control in bone marrow transplant patients. Infect Control Hosp Epidemiol. 1997;18(6):412-6.

35. Rosa RG, Tonietto TF, da Silva DB, et al. Effectiveness and safety of an extended ICU visitation model for delirium prevention: a before and after study. Crit Care Med. 2017;45(10): $1660-7$. 
36. Malacarne P, Pini S, De Feo N. Relationship between pathogenic and colonizing microorganisms detected in intensive care unit patients and in their family members and visitors. Infect Control Hosp Epidemiol. 2008;29(7):679-81.

37. Malacarne P, Corini M, Petri D. Health care-associated infections and visiting policy in an intensive care unit. Am J Infect Control. 2011;39(10):898-900.

38. Tang CS, Chung FF, Lin MC, Wan GH. Impact of patient visiting activities on indoor climate in a medical intensive care unit: a 1-year longitudinal study. Am J Infect Control. 2009;37(3):183-8.

39. Polak J, Ringler N, Daugherty B. Unit based procedures: impact on the incidence of nosocomial infections in the newborn intensive care unit. Newborn Infant Nurs Rev. 2004;4(1):38-45.

40. Lofgren ET. Estimating the impact post randomization changes in staff behavior in infection prevention trials: a mathematical modeling approach. BMC Infect Dis. 2017;17(1):539.

41. Banach DB, Bearman GM, Morgan DJ, Munoz-Price LS. Infection control precautions for visitors to healthcare facilities. Expert Rev Anti-Infect Ther. 2015;13(9):1047-50.

42. Gallimore CI, Taylor C, Gennery AR, et al. Contamination of the hospital environment with gastroenteric viruses: comparison of two pediatric wards over a winter season. J Clin Microbiol. 2008;46(9):3112-5.

43. Birnbach DJ, Rosen LF, Fitzpatrick M, Arheart KL, Munoz-Price LS. An evaluation of hand hygiene in an intensive care unit: are visitors a potential vector for pathogens? J Infect Public Health. 2015;8(6):570-4.

44. Clock SA, Cohen B, Behta M, Ross B, Larson EL. Contact precautions for multidrugresistant organisms: current recommendations and actual practice. Am J Infect Control. 2010;38(2):105-11.

45. Afif W, Huor P, Brassard P, Loo VG. Compliance with methicillin-resistant Staphylococcus aureus precautions in a teaching hospital. Am J Infect Control. 2002;30(7):430-3.

46. Nishimura S, Kagehira M, Kono F, Nishimura M, Taenaka N. Handwashing before entering the intensive care unit: what we learned from continuous video-camera surveillance. Am J Infect Control. 1999;27(4):367-9.

47. Fakhry M, Hanna GB, Anderson O, Holmes A, Nathwani D. Effectiveness of an audible reminder on hand hygiene adherence. Am J Infect Control. 2012;40(4):320-3.

48. Kellerman SE, Saiman L, San Gabriel P, Besser R, Jarvis WR. Observational study of the use of infection control interventions for Mycobacterium tuberculosis in pediatric facilities. Pediatr Infect Dis J. 2001;20(6):566-70.

49. Said MA, Perl TM, Sears CL. Healthcare epidemiology: gastrointestinal flu: norovirus in health care and long-term care facilities. Clin Infect Dis. 2008;47(9):1202-8.

50. Centers for Disease Control and Prevention. Principles of epidemiology in public health practice, third edition: an introduction to applied epidemiology and biostatistics. 2016. https:// www.cdc.gov/ophss/csels/dsepd/ss1978/lesson6/section2.html\#step2. Accessed 15 Jan 2018.

51. George RH, Gully PR, Gill ON, Innes JA, Bakhshi SS, Connolly M. An outbreak of tuberculosis in a children's hospital. J Hosp Infect. 1986;8(2):129-42.

52. Bosley AR, George G, George M. Outbreak of pulmonary tuberculosis in children. Lancet. 1986;1(8490):1141-3.

53. Weinstein JW, Barrett CR, Baltimore RS, Hierholzer WJ Jr. Nosocomial transmission of tuberculosis from a hospital visitor on a pediatrics ward. Pediatr Infect Dis J. 1995;14(3):232-4.

54. Halasa NB, Williams JV, Wilson GJ, Walsh WF, Schaffner W, Wright PF. Medical and economic impact of a respiratory syncytial virus outbreak in a neonatal intensive care unit. Pediatr Infect Dis J. 2005;24(12):1040-4.

55. Committee on Infectious Diseases. From the American Academy of Pediatrics: policy statements - modified recommendations for use of palivizumab for prevention of respiratory syncytial virus infections. Pediatrics. 2009;124(6):1694-701.

56. Friesema IH, Vennema H, Heijne JC, et al. Norovirus outbreaks in nursing homes: the evaluation of infection control measures. Epidemiol Infect. 2009;137(12):1722-33.

57. Johnston CP, Qiu H, Ticehurst JR, et al. Outbreak management and implications of a nosocomial norovirus outbreak. Clin Infect Dis. 2007;45(5):534-40. 
58. Buchbinder N, Dumesnil C, Pinquier D, et al. Pandemic A/H1N1/2009 influenza in a paediatric haematology and oncology unit: successful management of a sudden outbreak. J Hosp Infect. 2011;79(2):155-60.

59. Munoz FM, Campbell JR, Atmar RL, et al. Influenza A virus outbreak in a neonatal intensive care unit. Pediatr Infect Dis J. 1999;18(9):811-5.

60. Centers for Disease Control and Prevention. Revised U.S. surveillance case definition for severe acute respiratory syndrome (SARS) and update on SARS cases - United States and worldwide, December 2003. MMWR Morb Mortal Wkly Rep. 2003;52(49):1202-6.

61. Mukhopadhyay A, Tambyah PA, Singh KS, Lim TK, Lee KH. SARS in a hospital visitor and her intensivist. J Hosp Infect. 2004;56(3):249-50.

62. Gopalakrishna G, Choo P, Leo YS, et al. SARS transmission and hospital containment. Emerg Infect Dis. 2004;10(3):395-400.

63. Dwosh H, Hong H, Austgarden D, Herman S, Schabas R. Identification and containment of an outbreak of SARS in a community hospital. CMAJ. 2003;168(11):1415-20.

64. Shuler SN, Reich CA. Sibling visitation in pediatric hospitals: policies, opinions, and issues. Child Health Care. 1982;11(2):54-60.

65. Moore KA, Coker K, DuBuisson AB, Swett B, Edwards WH. Implementing potentially better practices for improving family-centered care in neonatal intensive care units: successes and challenges. Pediatrics. 2003;111(4 Pt 2):e450-60.

66. Meyer EC, Kennally KF, Zika-Beres E, Cashore WJ, Oh W. Attitudes about sibling visitation in the neonatal intensive care unit. Arch Pediatr Adolesc Med. 1996;150(10):1021-6.

67. Committee on Infectious Diseases, American Academy of Pediatrics. Infection Control and Prevention for Hospitalized Children: Sibling Visitation. In: Kimberlin DW, Brady MT, Jackson MA, Long SS, editors. Red Book. 30th ed. Elk Grove Village: American Academy of Pediatrics; 2015. p. 173.

68. Poster EC, Betz CL. Survey of sibling and peer visitation policies in southern California hospitals. Child Health Care. 1987;15(3):166-71.

69. Simon K. Perceived stress of nonhospitalized children during the hospitalization of a sibling. J Pediatr Nurs. 1993;8(5):298-304.

70. Cairns NU, Clark GM, Smith SD, Lansky SB. Adaptation of siblings to childhood malignancy. J Pediatr. 1979;95(3):484-7.

71. Meyendorf R. Infant depression due to separation from siblings: syndrome of depression, retardation, starvation, and neurological symptoms. A re-evaluation of the concept of maternal deprivation. Psychiatr Clin (Basel). 1971;4(5):321-35.

72. Petrillo M. Preparing children and parents for hospitalization and treatment. Pediatr Ann. 1972;1(3):24-41.

73. Craft MJ, Wyatt N, Sandell B. Behavior and feeling changes in siblings of hospitalized children. Clin Pediatr (Phila). 1985;24(7):374-8.

74. Knafl KA. Parents' views of the response of siblings to a pediatric hospitalization. Res Nurs Health. 1982;5(1):13-20.

75. Hartling L, Milne A, Tjosvold L, Wrightson D, Gallivan J, Newton AS. A systematic review of interventions to support siblings of children with chronic illness or disability. J Paediatr Child Health. 2014;50(10):E26-38.

76. Youngblut JM, Shiao SY. Child and family reactions during and after pediatric ICU hospitalization: a pilot study. Heart Lung. 1993;22(1):46-54.

77. Rozdilsky JR. Enhancing sibling presence in pediatric ICU. Crit Care Nurs Clin North Am. 2005;17(4):451-61, xii.

78. Craft MJ. Validation of responses reported by school-aged siblings of hospitalized children. Child Health Care. 1986;15(1):6-13.

79. Craft MJ, Craft JL. Perceived changes in siblings of hospitalized children: a comparison of sibling and parent reports. Child Health Care. 1989;18(1):42-8.

80. Committee on Hospital Care, Child Life Council. Child life services. Pediatrics. 2014;133(5):e1471-8.

81. Oehler JM, Vileisis RA. Effect of early sibling visitation in an intensive care nursery. J Dev Behav Pediatr. 1990;11(1):7-12. 
82. Montgomery LA, Kleiber C, Nicholson A, Craft-Rosenberg M. A research-based sibling visitation program for the neonatal ICU. Crit Care Nurse. 1997;17(2):29-35, 38-40.

83. Gursky B. The effect of educational interventions with siblings of hospitalized children. J Dev Behav Pediatr. 2007;28(5):392-8.

84. Beickert K, Mora K. Transforming the pediatric experience: the story of child life. Pediatr Ann. 2017;46(9):e345-51.

85. Smith L, Medves J, Harrison MB, Tranmer J, Waytuck B. The impact of hospital visiting hour policies on pediatric and adult patients and their visitors. JBI Libr Syst Rev. 2009;7(2):38-79.

86. D’Arcy N, Cloutman-Green E, Klein N, Spratt DA. Environmental viral contamination in a pediatric hospital outpatient waiting area: implications for infection control. Am J Infect Control. 2014;42(8):856-60.

87. Umphenour JH. Bacterial colonization in neonates with sibling visitation. JOGN Nurs. 1980;9(2):73-5.

88. Wranesh BL. The effect of sibling visitation on bacterial colonization rate in neonates. JOGN Nurs. 1982;11(4):211-3.

89. Solheim K, Spellacy C. Sibling visitation: effects on newborn infection rates. J Obstet Gynecol Neonatal Nurs. 1988;17(1):43-8.

90. Spear HJ. Child visitation policy and practice for maternity units. MCN Am J Matern Child Nurs. 2009;34(6):372-7.

91. Gupta M, Pursley DM. A survey of infection control practices for influenza in mother and newborn units in US hospitals. Am J Obstet Gynecol. 2011;204(6 Suppl):S77-83.

92. Visiting hours. 2018. https://www.childrensomaha.org/visiting-hours. Accessed 15 Jan 2018.

93. For vistors: visiting and deliveries. 2018. http://www.seattlechildrens.org/visitors/visiting/. Accessed 15 Jan 2018.

94. Visiting hours and policies. 2018. https://www.urmc.rochester.edu/childrens-hospital/visitorinformation/visiting-hours.aspx. Accessed 15 Jan 2018.

95. 2017 - 2018 APPA national pet owners survey. 2017. http://www.americanpetproducts.org/ pubs_survey.asp.

96. Chu CI, Liu CY, Sun CT, Lin J. The effect of animal-assisted activity on inpatients with schizophrenia. J Psychosoc Nurs Ment Health Serv. 2009;47(12):42-8.

97. Stasi MF, Amati D, Costa C, et al. Pet-therapy: a trial for institutionalized frail elderly patients. Arch Gerontol Geriatr Suppl. 2004;9:407-12.

98. Cole KM, Gawlinski A, Steers N, Kotlerman J. Animal-assisted therapy in patients hospitalized with heart failure. Am J Crit Care. 2007;16(6):575-85; quiz 586; discussion 587-578.

99. Braun C, Stangler T, Narveson J, Pettingell S. Animal-assisted therapy as a pain relief intervention for children. Complement Ther Clin Pract. 2009;15(2):105-9.

100. Caprilli S, Messeri A. Animal-assisted activity at A. Meyer Children's Hospital: a pilot study. Evid Based Complement Alternat Med. 2006;3(3):379-83.

101. Bouchard F, Landry M, Belles-Isles M, Gagnon J. A magical dream: a pilot project in animalassisted therapy in pediatric oncology. Can Oncol Nurs J. 2004;14(1):14-7.

102. Lefebvre SL, Waltner-Toews D, Peregrine AS, et al. Prevalence of zoonotic agents in dogs visiting hospitalized people in Ontario: implications for infection control. J Hosp Infect. 2006;62(4):458-66.

103. Snider R, Landers S, Levy ML. The ringworm riddle: an outbreak of Microsporum canis in the nursery. Pediatr Infect Dis J. 1993;12(2):145-8.

104. Mossovitch M, Mossovitch B, Alkan M. Nosocomial dermatophytosis caused by Microsporum canis in a newborn department. Infect Control. 1986;7(12):593-5.

105. Richet HM, Craven PC, Brown JM, et al. A cluster of Rhodococcus (Gordona) Bronchialis sternal-wound infections after coronary-artery bypass surgery. N Engl J Med. 1991;324(2):104-9.

106. Lyons RW, Samples CL, DeSilva HN, Ross KA, Julian EM, Checko PJ. An epidemic of resistant Salmonella in a nursery. Animal-to-human spread. JAMA. 1980;243(6):546-7.

107. Chang HJ, Miller HL, Watkins N, et al. An epidemic of Malassezia pachydermatis in an intensive care nursery associated with colonization of health care workers' pet dogs. N Engl J Med. 1998;338(11):706-11. 
108. Scott GM, Thomson R, Malone-Lee J, Ridgway GL. Cross-infection between animals and man: possible feline transmission of Staphylococcus aureus infection in humans? J Hosp Infect. 1988;12(1):29-34.

109. Bert F, Gualano MR, Camussi E, Pieve G, Voglino G, Siliquini R. Animal assisted intervention: a systematic review of benefits and risks. Eur J Integr Med. 2016;8(5):695-706.

110. Murthy R, Bearman G, Brown S, et al. Animals in healthcare facilities: recommendations to minimize potential risks. Infect Control Hosp Epidemiol. 2015;36(5):495-516.

111. US Department of Health and Human Services, Centers for Disease Control and Prevention. Guidelines for environmental infection control in health-care facilities. Atlanta: CDC (Centers for Disease Control). 2018. https://www.cdc.gov/infectioncontrol/pdf/guidelines/ environmental-guidelines.pdf. Accessed 28 Sept 2018.

112. Committee on Infectious Diseases, American Academy of Pediatrics, Kimberlin D, Brady M, Jackson M, Long S. Recommendations for care of children in special circumstances. In: Kimberlin DW, Brady MT, Jackson MA, Long SS, editors. Red book. 30th ed. Elk Grove Village: American Academy of Pediatrics; 2015. p. 174-5.

113. Ivany A, LeBlanc C, Grisdale M, Maxwell B, Langley JM. Reducing infection transmission in the playroom: balancing patient safety and family-centered care. Am J Infect Control. 2016;44(1):61-5.

114. da Silva JR, Pizzoli LM, Amorim AR, et al. Using therapeutic toys to facilitate venipuncture procedure in preschool children. Pediatr Nurs. 2016;42(2):61-8.

115. Dales RE, Cakmak S, Brand K, Judek S. Respiratory illness in children attending daycare. Pediatr Pulmonol. 2004;38(1):64-9.

116. Nafstad P, Hagen JA, Oie L, Magnus P, Jaakkola JJ. Day care centers and respiratory health. Pediatrics. 1999;103(4 Pt 1):753-8.

117. Barros AJ. Child-care attendance and common morbidity: evidence of association in the literature and questions of design. Rev Saude Publica. 1999;33(1):98-106.

118. Cote SM, Petitclerc A, Raynault MF, et al. Short- and long-term risk of infections as a function of group child care attendance: an 8-year population-based study. Arch Pediatr Adolesc Med. 2010;164(12):1132-7.

119. Fraser A, Wohlgenant K, Cates S, et al. An observational study of frequency of provider hand contacts in child care facilities in North Carolina and South Carolina. Am J Infect Control. 2015;43(2):107-11.

120. Mahl MC, Sadler C. Virus survival on inanimate surfaces. Can J Microbiol. 1975;21(6):819-23.

121. Hughes WT, Williams B, Williams B, Pearson T. The nosocomial colonization of T. Bear. Infect Control. 1986;7(10):495-500.

122. Buttery JP, Alabaster SJ, Heine RG, et al. Multiresistant Pseudomonas aeruginosa outbreak in a pediatric oncology ward related to bath toys. Pediatr Infect Dis J. 1998;17(6):509-13.

123. Rogers M, Weinstock DM, Eagan J, Kiehn T, Armstrong D, Sepkowitz KA. Rotavirus outbreak on a pediatric oncology floor: possible association with toys. Am J Infect Control. 2000;28(5):378-80.

124. Avila-Aguero ML, German G, Paris MM, Herrera JF, Safe Toys Study G. Toys in a pediatric hospital: are they a bacterial source? Am J Infect Control. 2004;32(5):287-90.

125. Boretti VS, Correa RN, dos Santos SS, Leao MV, Goncalves e Silva CR. Sensitivity profile of Staphylococcus spp. and Streptococcus spp. isolated from toys used in a teaching hospital playroom. Rev Paul Pediatr. 2014;32(3):151-6.

126. Ruiz R, Quijandria J, Rojas-Vilca JL, Loyola S. High number of toys contaminated with Staphylococcus aureus in a pediatric hospitalization service. Rev Peru Med Exp Salud Publica. 2016;33(4):830-2.

127. Carducci A, Verani M, Lombardi R, Casini B, Privitera G. Environmental survey to assess viral contamination of air and surfaces in hospital settings. J Hosp Infect. 2011;77(3):242-7.

128. Siani H, Maillard JY. Best practice in healthcare environment decontamination. Eur J Clin Microbiol Infect Dis. 2015;34(1):1-11.

129. Evans HL, Shaffer MM, Hughes MG, et al. Contact isolation in surgical patients: a barrier to care? Surgery. 2003;134(2):180-8. 
130. Saint S, Higgins LA, Nallamothu BK, Chenoweth C. Do physicians examine patients in contact isolation less frequently? A brief report. Am J Infect Control. 2003;31(6):354-6.

131. Kirkland KB, Weinstein JM. Adverse effects of contact isolation. Lancet. 1999;354(9185):1177-8.

132. Stelfox HT, Bates DW, Redelmeier DA. Safety of patients isolated for infection control. JAMA. 2003;290(14):1899-905.

133. Klein BS, Perloff WH, Maki DG. Reduction of nosocomial infection during pediatric intensive care by protective isolation. N Engl J Med. 1989;320(26):1714-21.

134. Cohen E, Austin J, Weinstein M, Matlow A, Redelmeier DA. Care of children isolated for infection control: a prospective observational cohort study. Pediatrics. 2008;122(2):e411-5.

135. Abad C, Fearday A, Safdar N. Adverse effects of isolation in hospitalised patients: a systematic review. J Hosp Infect. 2010;76(2):97-102.

136. Wassenberg MW, Severs D, Bonten MJ. Psychological impact of short-term isolation measures in hospitalised patients. J Hosp Infect. 2010;75(2):124-7.

137. Day HR, Perencevich EN, Harris AD, et al. Depression, anxiety, and moods of hospitalized patients under contact precautions. Infect Control Hosp Epidemiol. 2013;34(3):251-8.

138. Findik UY, Ozbas A, Cavdar I, Erkan T, Topcu SY. Effects of the contact isolation application on anxiety and depression levels of the patients. Int J Nurs Pract. 2012;18(4):340-6.

139. Austin D, Prieto J, Rushforth H. The child's experience of single room isolation: a literature review. Nurs Child Young People. 2013;25(3):18-24.

140. Koller DF, Nicholas DB, Goldie RS, Gearing R, Selkirk EK. When family-centered care is challenged by infectious disease: pediatric health care delivery during the SARS outbreaks. Qual Health Res. 2006;16(1):47-60.

141. Chan SS, Leung D, Chui H, et al. Parental response to child's isolation during the SARS outbreak. Ambul Pediatr. 2007;7(5):401-4.

142. Forsner M, Jansson L, Soderberg A. Afraid of medical care school-aged children's narratives about medical fear. J Pediatr Nurs. 2009;24(6):519-28.

143. Rees J, Davies HR, Birchall C, Price J. Psychological effects of source isolation nursing (2): patient satisfaction. Nurs Stand. 2000;14(29):32-6. 